\title{
Challenges of locally manufactured vehicle supply chains in South Africa
}

\author{
Authors: \\ Intaher M. Ambe \\ Johanna A. Badenhorst- \\ Wess $^{1}$ \\ Affiliations: \\ ${ }^{1}$ Department of Business \\ Management, University of \\ South Africa, South Africa \\ Correspondence to: \\ Intaher Ambe \\ Email: \\ ambeim@unisa.ac.za \\ Postal address: \\ PO Box 392, UNISA, 0003, \\ South Africa \\ Dates: \\ Received: 11 Apr. 2013 \\ Accepted: 25 May 2013 \\ Published: 16 Aug. 2013 \\ How to cite this article: \\ Ambe, I.M. \& Badenhorst- \\ Wess, J.A., 2013, 'Challenges \\ of locally manufactured \\ vehicle supply chains in \\ South Africa', Journal of \\ Transport and Supply Chain \\ Management 7(1), Art. \#100, \\ 8 pages. http://dx.doi.org/ \\ 10.4102/jtscm.v7i1.100

\section{Copyright:} \\ (C) 2013. The Authors. \\ Licensee: AOSIS \\ OpenJournals. This work \\ is licensed under the \\ Creative Commons \\ Attribution License.
}

Read online:

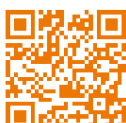

Scan this QR ode with your smart phone or mobile device to read online.
Locally manufactured vehicles are destined (partly) for the export market and thus, global competitiveness is important. This article explores the challenges facing supply chains of locally manufactured vehicles in South Africa. The automotive industry is perceived to be the most advanced in supply chain management practices in South Africa. It has embraced technology and management practices that have transformed the manufacturing environment by using cutting-edge design and visualisation tools. However, the industry has fragilities and faces new and emerging supply chain challenges. A survey research design was employed and the data was collected through face-to-face semi-structured interview questionnaires based on the purposive sampling technique. Data analysis and interpretation was based on descriptive statistics using SPSS software. The findings revealed that there are challenges hindering best supply chain practices of local vehicle manufacturers. The research also revealed that there is a perceived difference in supply chain challenges between the different manufacturers of different origins in South Africa. Asian manufacturers felt much stronger about the adequacy of their information systems compared to the European manufacturers. Asian manufacturers tended to agree more than their European counterparts that labour problems were a challenge. European manufacturers, on the other hand, tended to agree more that rail transport is unreliable. This article contributes to the body of knowledge on supply chain practices in South Africa.

\section{Introduction}

A large amount of locally manufactured vehicles in South Africa are destined for the export market, which affects the balance of payment and employment in the country. It is therefore important that these vehicle supply chains stay globally competitive. Because of this, it was decided to focus a study, and this article particularly, on the supply chains of locally manufactured vehicles. Supply chain management (SCM) has undergone transformation in the last two decades (Cooney \& Yacobucci 2005; Swieki \& Gerth 2008:2). Traditionally in the automotive industry, supply chains revolved mainly around making supplier collaboration and manufacturing operations more efficient (Lam 2008). However, with the boom of the Internet, data have become much more accessible to both manufacturers and consumers (Tang \& Qian 2008:288). The industry has tended to reduce inventory levels rapidly, forcing automotive component companies to redesign and expand their SCM initiatives (Hugo, Badenhorst \& Van Biljon 2004:76). First-tier suppliers are becoming increasingly important as design is pushed up the supply chain by original equipment manufacturers (OEMs) (Braese 2005:14).

According to Zhang and Chen (2006:66), real-time sharing of design, planning, production, logistics and sales information have served to make the 'global automotive industry' truly global. Globalisation has added complexities and costs to capture and maintain market share (Swieki \& Gerth 2008:2). In Asian markets, more than 20 new OEMs, joint ventures and thousands of suppliers were positioning to capture a piece of the projected 140 million new vehicle owners in China by 2010 (Deloitte Touche Tohmatsu 2009). In Eastern Europe, lower cost structures and the availability of highly skilled labour enticed OEMs and suppliers to establish new facilities, technology and design centres. Point-to-point technology solutions were used to leverage the ubiquitous, low-cost capabilities of the Internet (Zhang \& Chen 2006:668). First-tier suppliers and OEMs looked to extend demand-driven capabilities to $100 \%$ of the supply chain. In mature markets, automotive firms faced stiff competition and demanding customers (Afsharipour, Afshari \& Sahaf 2006:5).

In South Africa, SCM is one of the important functional areas in the automotive industry and its contribution has been particularly noteworthy (Pires \& Neto 2008:328). The industry sector's contribution to 7\% of South Africa's gross domestic product (GDP) was R3251.4 billion in 2012 
(Automotive Industry Export Council [AIEC] 2013:7). Because of intensified competition in the global market, the introduction of products with shorter lifecycles and growing customer service, vehicle manufacturers in South Africa have been forced to invest in and direct their attention to the supply chains (Naude \& Badenhorst-Weiss 2011:70). Preliminary investigation revealed that although the industry is important in South Africa, it poses critical SCM challenges for local manufacturers and it is internationally uncompetitive. The Supply Chain Intelligence report (CSIR 2009) revealed that the majority of companies in the industry do not only operate with low levels of collaboration, but are also not market-sensitive or reactive to the changing market. The Supply Chain Foresight report (2010) highlighted the fact that the industry supply chain is more vulnerable than ever as a result of vast swings in demand and volumes because of the global recession. Naude and Badenhorst-Weiss (2011:96) asserted that automotive component manufacturers (ACMs) feel pressure from OEMs to reduce prices and are restrained by excessive inventory, the unreliability of rail transport, rail capacity problems and the high cost of South African ports. Low levels of collaboration and stiff competition among manufacturers challenge the industry (Lamprecht 2009:159; Mphahlwa 2008:2).

These challenges hinder the efficient and effective implementation of SCM practices by vehicle manufacturers in South Africa. In light to this, the automotive industry is challenged to maintain its position in the market, to produce at a competitive cost and to have the ability to respond quickly and reliably to first-world market demands (Ambe \& Badenhorst-Weiss 2011:355). This article provides an understanding of the challenges in the supply chain, which is not only paramount for locally manufactured vehicle supply chain practitioners, but also for the automotive industry and South Africa as a whole. In this regard, the purpose of this article is defined by the following research questions:

- What are the supply chain challenges faced by vehicle manufacturers of locally manufactured models in South Africa?

- Is there a difference between supply chain challenges faced by manufacturers of different origins in South Africa?

The remaining sections of the article present the literature review, research methodology, discussion of the results and conclusion.

\section{Literature review}

The literature review discusses the definition of supply chain management, SCM practices in the automotive industry and SCM challenges in the South African automotive industry.

\section{Definition of supply chain management}

According to Leenders and Fearon:

Supply chain management is the systems approach to managing the entire flow of information, materials and services from the raw materials suppliers through factories and warehouses to the end customer (2004:10).
Christopher (2005:5) defined SCM as 'the management of upstream and downstream relationships with suppliers and customers to deliver superior customer value at less cost to the supply chain as a whole'. According to Wisner, Tan and Leong (2008:8), SCM is 'the design and management of seamless, value-added processes across organisational boundaries to meet the real needs of the end customer'. The above definitions represent the various views of many literature sources. Although the definitions of SCM differ to some extent, they can be classified into three categories: a management philosophy, implementation of a management philosophy and as a set of management processes (Klemencic 2006:13; Lambert 2006).

\section{Overview of the global automotive industry}

The automotive industry is one of the most global industries, with its products spread around the world and dominated by small companies enjoying worldwide recognition (Barnes \& Morris 2008:32; Humphrey \& Memedovic 2003:2). The industry comprises the largest manufacturing sector in the world, with an output equivalent to that of the world's sixth largest economy (Nag, Banerjee \& Chatterjee 2007:1; Organisation Internationale des Constructuers d'Automobiles [OICA] 2008). The industry is also one of the largest investors in research and development (R\&D), thus playing a key role in society-wide technological development (Commonwealth of Australia 2008; Organisation Internationale des Constructuers d'Automobiles [OICA] 2009). The industry is capital intensive and technologically advanced, both in terms of manufacturing processes and its products (Wei \& Chen 2008:973).

Within the industry, the level of competition is increasing and the production base of most auto-giant companies is being shifted from the developed countries to developing countries in order to take advantage of low-cost production (Nag et al. 2007:4). Automotive products have spread around the world and are dominated by a small number of companies with worldwide recognition. Due to the increasing number of vehicle models being introduced into segmented markets, executive managers are seeking both growth and cost reductions to make their companies more competitive and profitable. Vehicles are becoming more complex in order to satisfy consumer demands for improvements in safety, fuel economy, performance and quality. Automobile manufacturers are constantly under pressure to identify consumer preferences, national biases and new market segments where they can sell vehicles and gain market share. Their ability to be flexible enough to quickly respond to all of these pressures is determining their future in the industry. The implications of these factors are vast and propagate along the supply chain of the automakers (Veloso \& Kumar 2003:2).

\section{The South African automotive industry}

South Africa's automotive industry is a global, turbo-charged engine for the manufacture and export of vehicles and components. South Africa has developed a major automotive 
industry with local vehicle manufacturing plants for Volkswagen, BMW, Nissan, General Motors, Ford, MercedesBenz and Toyota (Van der Merwe \& Visser 2008). Since the early 1990s, the South African automotive industry has been through a rapid process of adjustment as protection has been reduced (Black 2001:3). The globalisation of the industry has received much attention and the focus has been on the rapid increase in automotive exports. The industry is distinguished from other industrial sectors by the role of government policies steering its development (Lamprecht 2009:7). The motor industry development programme (MIDP), which was introduced in 1995, has played a very significant role in promoting competitiveness and export expansion. The MIDP provided an effective platform for communication and co-operation for all of the relevant stakeholders to interact on automotive issues. The stakeholders in the automotive industry include government, labour and business (Department of Trade and Industry [DTI] 2004).

As stated by the AIEC (2013:4) report, the automotive production development programme (APDP) has replaced the MIDP. Under the APDP, which commenced 01 January 2013, the South African automotive industry entered an era of volume-driven production support. Kehbila, Ertel and Brent (2009:310) asserted that the industry is the largest manufacturing sector in South Africa. About nine million people worldwide are directly employed in producing the vehicles and the automotive components that go into them (AIEC 2012:13). According to the AIEC's report (2012:13), it is estimated that each direct automotive job supports at least another five indirect jobs, resulting in more than 50 million jobs globally in the automotive industry. The industry sector's contribution to South Africa's gross domestic product (GDP) was R3251.4 b in 2012 and amounted to 7\% (AIEC 2013:7). The South African automotive industry exported left- hand drive and right-hand drive vehicles to 87 destinations in 2012. In 2012, 277893 completely built-up vehicles (CBU) were exported from South Africa, comprising of: 153196 or 55.1\% passenger cars; 123623 or $44.5 \%$ light commercial vehicles; and 1074 or $0.4 \%$ medium and heavy commercial vehicles and buses. Light commercial vehicle export increased by a significant $47.0 \%$ or 39498 units, from 84125 units in 2011 to 123623 units in 2012 (AIEC 2013:58).

\section{Supply chain challenges in the South African automotive industry}

Whilst the automotive industry is critical to the South African economy, it faces enormous challenges in the supply chain. According to the Kotler Marketing Group (2009), from a global perspective, the automotive industry is faced with some of the most difficult and challenging circumstances, so OEMs are scrambling to slash production and reduce manufacturing costs. They are required to enhance quality, improve styling, increase organisational efficiencies and drive innovative features into their products in an effort to attract customers and expand into new markets. They are continually putting pressure on their tiered suppliers to reduce costs, increase output and quality. These challenges imply that automotive manufacturers need to be flexible and responsive to customer demand in order to succeed. Pires and Neto (2008:328) noted that the automotive industry has, in recent years, experienced strong competition on a global scale in highly competitive markets. It has been challenged to face issues such as: strong pressure for price and delivery time reductions; quality and overall customer service improvements; environmentally friendly products; a substantial reduction in product life cycles; the rapid introduction of new products; a reduction in the time-tomarket and product development costs; the pressure to supply new markets, both in geographical terms and in terms of new products; the strengthening of relationships and the intensification of communication channels in supply chains in general (Pires \& Cardoza 2007).

Government trade, safety and environmental regulations are also influential factors affecting the automotive industry (Schwarz 2008:2). It is clear that supply chain challenges may stem from the external environment, the customers, competition and the auto industry. In addition to these challenges, automakers in South Africa experience long order-to-delivery lead times and unreliable production schedules that lead to excess inventory throughout the supply chain. Lengthy demand planning cycles and lack of visibility to supplier, material and production constraints cause scheduling delays and short-term production changes. These problems drive automakers and suppliers to build up buffer inventory and limit their ability to flexibly react to changes in customer demand.

Under these conditions, suppliers are unable to sense customer orders and manufacture solely on schedules with 12-16 weeks of lead-time. Constrained, inflexible production and assembly capacities, and long delivery lead times also contribute to high dealer inventory levels in the form of safety stock (Schwarz 2008:2). Besides, there is lack of transparency and effective connectivity to partners. Another supply chain issue that affects the automotive industry is a lack of collaboration in product development. Communication channels between OEMs and other supply chain partners remain manual in many cases. This is especially true in the case of small suppliers unable to afford an investment in electronic data interchange (EDI) technology that is used between OEMs and their larger suppliers. Logistics operations in the automotive supply chain are complex and represent a major expense and opportunity for improvement. The lack of communication and co-ordination of inbound and outbound logistics operations often prevents automakers from optimising their supply chains, reducing inventories and accurately forecasting and responding to customer demands (Naude 2009:264).

In South Africa, the automotive industry faces new and pressing challenges (Muller 2009). As stated in the Supply Chain Foresight Report (2007), although the automobile industry in South Africa is in an advanced stage compared to other industries with regard to the management of the supply 
chain activities, the industry faces challenges of pressure for cost reduction and service improvement. The Supply Chain Intelligence Report (CSIR) (2009) indicated that the majority of companies in the automotive industry in South Africa do not only operate with low levels of collaboration, but are also not market-sensitive or reactive to the changing market. Also, the Supply Chain Foresight Report (2010) highlighted that the industry supply chain is more vulnerable than ever as a result of huge swings in demand and volumes experienced through the global recession.

In the study conducted by Naude (2009:99), important challenges for the South African automotive industry were identified, such as to produce at a competitive cost and to have the ability to respond quickly and reliably to first-world market demands. Naude (2009:265) further noted that the main supply chain problems in the South African automotive industry include: pressure by OEMs to reduce prices; the price of materials; cancellation of orders; excessive inventory; the unreliability of rail transport and rail capacity problems; the high cost of South African ports; the cost of replacing outdated technology; and BBBEE - achieving and verifying BEE scorecards. Furthermore, a lack of skills and labour problems, both of which are time-consuming to resolve, also play a role.

Also, logistics issues are a challenge. Although South Africa has improved on the World Bank logistics performance index (WBLPI) (ranked 28th in 2010 and 23rd in 2012 among 155 countries), logistics is still a challenge (WBLPI 2012). According to Viljoen (2012) transport costs are the single greatest factor impacting on South Africa's logistics costs, comprising $53.2 \%$ of the logistics bill. The country is faced with severe skills shortages and lack of economies of scale (Viljoen 2012). Muller (2009) highlighted a number of issues that are currently impacting on the competitiveness of the South African automotive industry. These include: globalisation and market convergence - owing to the effects of liberalisation, national markets are increasingly globalised; individualisation - consumers are being spoilt for choice and are no longer satisfied to accept standardised products. Products need to be tailored and tailorable in order to satisfy individual requirements and accelerated modification and diversification of the product portfolio are necessary. Manufacturers therefore have to shorten product lifecycles in order to react with innovative products to the expectations of changing consumer demands; they must regulate and increase safety requirements. There are also increased pressures for innovation and flexibility in development and manufacturing.

If one looks at the studies and reports outlined above there is a pattern that shows that local (South African) circumstances, economic conditions, inefficiencies in supply chains, customer pressure and global competition are to blame for the tremendous pressure on the local automotive industry. The focus of this article is particularly on supply chains of locally manufactured vehicle models and not on the industry or certain role players in the industry.

\section{Research methodology}

The purpose of this research was to explore the challenges facing locally produced vehicle supply chains in South Africa. To achieve this objective, an exploratory and descriptive research design in the form of a survey was used to collect the data. The research instrument was a semi-structured face-toface interview questionnaire, which was conducted between June 2012 and September 2012. The target population was original equipment manufacturers (OEMs) in South Africa that produced locally made light vehicles. These OEMs are the most important and powerful players in locally produced vehicle supply chains. A purposive sampling technique was used to determine the respondents. The purposive sampling technique was used in order to concentrate on those who have expert knowledge about supply chain practices and operations in the automotive industry (senior supply chain managers). Therefore, specific participants for interviews were selected according to their strategic positions in the supply chain. A total of twelve $(n=12)$ indepth structured interviews were conducted from six light vehicle manufacturers. The data for this study were analysed descriptively using Statistical Package for the Social Sciences (SPSS). The open-ended responses were used to give more meaning to the respondents' views on questions where it was applicable (Gray, Williamson, Karp \& Dalphin 2007:44).

\section{Discussion of the results}

The discussion of the results is presented in two parts. The first part relates to the challenges in the supply chain, whilst the second part relates to the perceived differences in the challenges between manufacturers of different parental origin.

\section{Supply chain challenges facing light vehicle manufacturers}

A questionnaire was used as the research tool during the interviews. Respondents were asked to indicate their level of agreement on a five-point Likert response format ranging from 1 (strongly disagree) to 5 (strongly agree) with reference to the extent to which statements in Table 1 impact on their performance. Twenty-three statements representing potential challenges were included. The respondents were also asked to identify other challenges that were not stated. For the purpose of analysis, the challenges were grouped into technological challenges, infrastructural challenges, cost challenges, market or service challenges, relationship challenges and skills challenges. The frequency distribution (in \%) per statement is presented in Table 1.

\section{Technological challenges}

The majority of the respondents did not agree with the statement about 'inadequate information systems' and 'inefficient planning and forecasting tool' (75.0\%). Only 25.0\% of the respondents felt that these issues were a potential challenge. A total of $83.3 \%$ of the respondents indicated that they agree that 'high costs when replacing outdated 
TABLE 1: Challenges experienced in locally-produced light vehicle supply chains.

\begin{tabular}{|c|c|c|c|c|c|}
\hline Challenges & SD (\%) & $\mathrm{D}(\%)$ & $\mathbf{N}(\%)$ & $A(\%)$ & SA (\%) \\
\hline \multicolumn{6}{|l|}{ Technological challenges } \\
\hline Inadequate information systems. & 50.0 & 25.0 & 0.0 & 16.7 & 8.3 \\
\hline Inefficient planning and forecasting tool. & 50.0 & 25.0 & 0.0 & 25.0 & 0.0 \\
\hline Costly to replace outdated assembly or manufacturing tools. & 0.0 & 0.0 & 8.3 & 83.3 & 0.0 \\
\hline \multicolumn{6}{|l|}{ Infrastructural challenges } \\
\hline Lack of sustainable infrastructure. & 33.3 & 8.3 & 33.3 & 25.0 & 0.0 \\
\hline Unreliable rail transport. & 0.0 & 25.0 & 25.0 & 33.3 & 16.7 \\
\hline Rail capacity problems. & 16.7 & 33.3 & 50.0 & 0.0 & 0.0 \\
\hline Increased road freight volumes. & 8.3 & 8.3 & 16.7 & 33.3 & 33.3 \\
\hline Delays at ports. & 8.3 & 0.0 & 0.0 & 33.3 & 58.3 \\
\hline \multicolumn{6}{|l|}{ Cost challenges } \\
\hline High fuel costs affect our operating costs. & 0.0 & 0.0 & 0.0 & 41.7 & 58.4 \\
\hline Operating costs are high. & 0.0 & 0.0 & 8.3 & 58.3 & 16.7 \\
\hline Costs at South African ports are high. & 0.0 & 0.0 & 0.0 & 33.3 & 58.3 \\
\hline \multicolumn{6}{|l|}{ Market or service challenges } \\
\hline It is difficult to find a new market. & 8.3 & 8.3 & 25.0 & 41.7 & 16.7 \\
\hline Sometimes our customers cancel their order. & 0.0 & 8.3 & 16.7 & 41.7 & 33.3 \\
\hline We are challenged to improve our service level. & 8.3 & 25.0 & 0.0 & 25.0 & 41.7 \\
\hline \multicolumn{6}{|l|}{ Relationship challenges } \\
\hline $\begin{array}{l}\text { It is difficult to verify the BBBEE (broad-based black economic empowerment) status } \\
\text { (scorecards) of our strategic suppliers. }\end{array}$ & 41.7 & 25.0 & 16.7 & 8.3 & 0.0 \\
\hline It is sometimes difficult to collaborate with our strategic suppliers. & 25.0 & 33.3 & 8.3 & 25.0 & 0.0 \\
\hline It is sometimes difficult to collaborate with our strategic customers. & 33.3 & 25.0 & 16.7 & 16.7 & 0.0 \\
\hline We operate with a low level of collaboration. & 50.0 & 41.7 & 0.0 & 0.0 & 0.0 \\
\hline \multicolumn{6}{|l|}{ Production or skills challenges } \\
\hline Unreliable production schedules. & 33.3 & 58.3 & 0.0 & 8.3 & 0.0 \\
\hline Lack of capacity. & 16.7 & 8.3 & 33.3 & 25.0 & 16.7 \\
\hline Challenged by lack of skills. & 8.3 & 16.7 & 16.7 & 41.7 & 16.7 \\
\hline Challenged by labour problems. & 8.3 & 8.3 & 16.7 & 16.7 & 50.0 \\
\hline
\end{tabular}

$\mathrm{SD}$, strongly disagree; $\mathrm{D}$, disagree; $\mathrm{N}$, neither agree nor disagree; $\mathrm{A}$, agree; SA, strongly agree.

Note: Some of the percentages do not add up to $100 \%$ due to missing values because some respondents did not answer specific statements on the challenges.

assembly or manufacturing tools' is a challenge. The results show that information technology is highly utilised by the majority of the local manufacturers in the South African automotive industry. This confirms the report of the Supply Chain Intelligence Report (SCIR) (2009), which asserted that there is high usage of information technology in the South African automotive industry. Therefore our study shows that 'costly to replace existing assembly or manufacturing tools' is a great challenge for manufacturers.

\section{Infrastructural challenges}

The results with regard to infrastructure indicated distributed responses, with a third (33.3\%) of the respondents indicating that they were not sure if 'sustainable infrastructure' is a challenge; $33.3 \%$ disagreed, whilst $25.0 \%$ agreed that it is a challenge. 'Reliability of the rail' as a means of transportation was a potential challenge according to half (50.0\%) of the respondents. However, a quarter $(25.0 \%)$ of the respondents noted that they were unsure if it was a challenge and 25.0\% disagreed. In terms of 'rail capacity problems' encountered, $50.0 \%$ of the respondents asserted that it was not a challenge, whilst the other respondents $(50.0 \%)$ were unsure. Hence, none of the respondents indicated that there was a rail capacity problem. The majority of the respondents $(66.6 \%)$ agreed that 'increased road freight volume' is a challenge. Almost all the respondents agreed that the industry was challenged by 'delays at port' (91.7\%).
The results reveal that 'sustainable infrastructure' and 'rail capacity' are not serious challenges that could affect the performance of local manufacturers in South Africa. However, reliability of rail, delays at port and increased road freight volume are challenges that impact the performance of automotive manufacturers. The results confirm the findings of the AutoWorld report (2010); there are problems with congested ports and terminals, particularly in Durban. Nonetheless, there were some cases where respondents were not sure if it was a challenge or not, such as 'unsustainable infrastructure' (33.3\%); 'unreliability of rail transport' (25.0\%) and 'rail capacity problems' (50.0\%). This could be due to the fact that the respondents do not have an opinion and some were not using rail transport and are therefore indifferent (only road transportation).

\section{Cost challenges}

In terms of costchallenges, 'high fuel costs' (100.0\% agreement) and 'incurring high costs at South African ports' recorded the highest ratings in agreement. Three quarters $(75.0 \%)$ of the respondents indicated that 'incurring high operating costs' were a challenge. Two thirds of the respondents $(66.6 \%)$ asserted that the 'high prices of material and components' were a challenge. This result also shows that cost is a major challenge in the South African automotive industry and confirms the findings of Naude and Badenhorst-Weiss (2011). 
Cost challenges, which include high fuel cost, operating cost, cost due to delays at ports and high prices of components and materials affect the performance of the industry and its competitive position worldwide. It is noted that the South African port charges are way higher than the other BRICS (Brazil, Russia, India, China) counterparts. This challenge obviously leads to high prices of new vehicles in South Africa and makes South African automotive manufacturers globally uncompetitive, which influences automobile exports. It takes an average South African 164 weeks of earnings to buy and finance an average priced new vehicle compared to just 26 weeks in the United States of America (Walker 2006).

\section{Market or service challenges}

Market and service challenges include issues that relate to finding new markets, cancellation of customer orders and improving service levels. The results indicate that just over half $(58.4 \%)$ of the respondents agreed that 'finding new markets' was a challenge. The majority (75\%) of the respondents indicated that 'customers cancelling their orders' is a challenge. 'Improving service levels' was also a challenge according to two thirds $(66.7 \%)$ of the respondents. This might be indicative that 'exploring new markets' is done by parent companies. Based on the results, it is evident that the South African automotive industry is challenged in its market and services; hence the need to improve service levels and explore new and emerging markets for exports. The result confirms the report by AutoWorld (2010), which states that the industry is still unfortunately not renowned for world-class service. If consumer fulfilments are attained as first priority, then the industry will have to work even harder to provide the demanding millennium customers with the level of service they expect. This challenge may also inhibit the industry from finding new supply markets due to competition from developing economies such as China, India and South America. Hence, South Africa may be in a better position to explore the African market.

\section{Relationship challenges}

In terms of relationships with partners in the supply chain, respondents were asked to indicate whether verifying the BBBEE status (scorecard) of their strategic suppliers was a challenge. Two thirds of the respondents asserted that it was not a challenge $(66.7 \%)$, whilst only $8.3 \%$ felt that verifying the BEE status was a challenge. Collaborating with strategic suppliers was not considered to be a challenge by more than half of the respondents (58.3\%) and only a quarter of the respondents $(25.0 \%)$ considered it to be a challenge. With reference to strategic customers, more than half of the respondents $(58.3 \%)$ confirmed that it was not a challenge to collaborate and only $16.7 \%$ of the respondents noted that it was a challenge. Lastly, all respondents (100.0\%) disagreed that they operate at a low level of collaboration, because the automotive industry is known for working closely (collaborating) with supply chain partners. The results show that there are good relationships with supply chain partners.

\section{Production or skills challenges}

In terms of production or skills challenges, the results show that unreliable production schedules were not a potential challenge as indicated by most $(91.6 \%)$ of the respondents. The responses for lack of capacity at production were dispersed, with $41.7 \%$ of the respondents asserting that it is a challenge, $33.3 \%$ of the respondents neither agreeing nor disagreeing and $25.0 \%$ of the respondents disagreeing. The challenge of a lack of skills recorded a high agreement rating $(58.4 \%)$, whilst a quarter $(25.0 \%)$ felt that it was not a challenge. Two thirds $(66.7 \%)$ of the respondents also considered labour problems to be a challenge.

According to the results, unreliable production schedules were not a major challenge. Capacity, skills and labour issues were challenges that impact on the performance of local automotive manufacturers in South Africa. The results confirm the findings of Naude and Badenhorst-Weiss (2011), who asserted that the South African component manufacturers experience capacity limitations due to a lack of skilled labour. Also, in South Africa it takes time to resolve labour disputes. It is important that the industry try to raise labour productivity as well as skills levels. Respondents were requested to state other critical challenges that were not listed. Box 1 summarises the challenges identified by respondents.

\section{Differences between supply chains with a different continent of origin (Asia and Europe) in terms of perceiving challenges}

Supply chains of local manufacturers are to a large extent dictated by the parent companies (in different countries) in terms of philosophy, design, processes, strategies and market schedules. In this part, this article explores the possibility of the influence of such parent companies on the perceived challenges in South Africa. To make a comparison viable, the respondents were divided into two groups - those who are from Asian origin and those of European origin. In this part of the results, the Mann-Whitney $U$-test was conducted to see whether there was a significant difference between the parent company's continent origin (Asia and Europe) with regard to how they perceive supply chain challenges. Hypotheses were developed to answer this question. The hypotheses tested for supply chain challenges were:

\section{BOX 1: Summary of additional challenges identified by respondents.}

High overhead cost, low productivity compared with other plants.
Engineering challenges in terms of part modifications where we experience
changes on the part while we have stock at sea freight.
Financially troubled suppliers.
Foreign exchange fluctuations.
Long lead-time to transport vehicles from East London to Gauteng; poor road
condition. Regulations.
All vehicles must be micro dotted (linked to VN number).
Long lead times can lead to obsolete parts. Quality problems at suppliers.
Tool breakdowns.
Market uncertainty with long reaction time.


Hypotheses 0: Local manufacturers of light vehicles of Asian and European origin do not show significant statistical differences with regard to the way they perceive supply chain challenges.

Hypotheses 1: Local manufacturers of Asian and European origins show significant statistical differences with regard to the way they perceive supply chain challenges.

Local manufacturers of light vehicles of European and Asian origin agree to a large extent about SCM challenges, except for three. Table 2 reflects the statements where statistically significant differences, at the $5 \%$ level of significance, were found between the OEM continents of origin (Asia and Europe) with regard to their supply chain performance indicators.

As indicated in Table 2, at 5\% significance level, there is a difference in the way that European and Asian manufacturers perceive three key supply chain challenges. Furthermore, Asian manufacturers (mean rank of 7.50) feel much stronger about adequacy of their information systems compared to the European manufacturers (Mean rank of 3.50). Asian manufactures furthermore tend to agree more (mean rank of 7.40) than their European counterparts (mean rank of 3.60) that labour problems are a challenge. European manufacturers, on the other hand, tend to agree more (mean rank 7.80) that rail transport is unreliable. Certain Asian manufacturing firms are well known for their world-class production and information systems, which is in line with the findings here. With regards to their opinion on labour problems, no explanation will be possible without further investigation. The differences with regard to unreliable rail transport may be explained by the geographical location of the companies, but this certainly requires further investigation. From the findings, it seems that local manufacturing supply chains' country (continent) of origin does not influence the challenges or problems face locally.

In conclusion, locally manufactured vehicle supply chains are particularly challenged by:

- cost to update technology;

- inefficiencies at ports;

- fuel price and port charges;

- improving service levels;

- cancelling of orders;

- capacity, skills and labour disputes (only to some extent).

These challenges, particularly port charges and fuel price, make South African locally made vehicles (of which a large part is made for the export market) uncompetitive, particularly if compared to other BRICS countries locally made vehicles for export.

\section{Conclusion}

This article explores the challenges facing vehicle manufacturers supply chains in South Africa. It answers two main research questions: (1) What are the challenges faced by vehicle manufacturers supply chains in South Africa? (2)
TABLE 2: Mann-Whitney test: Significant differences in views on supply chain.

\begin{tabular}{lccc}
\hline Challenges & \multicolumn{2}{c}{ Mean rank } & \multirow{2}{*}{$p$-value } \\
\cline { 2 - 3 } & Asia & Europe & \\
\hline We have inadequate information systems. & 7.50 & 3.50 & 0.018 \\
The rail transport is unreliable. & 3.20 & 7.80 & 0.013 \\
We are challenged by labour problems. & 7.40 & 3.60 & 0.034 \\
\hline
\end{tabular}

Is there a difference with reference to the challenges faced by manufacturers of different origins in South Africa?

South Africa currently exports locally manufactured vehicles to over 70 countries; it is challenged to maintain its position in the market and to produce at a competitive cost and to have the ability to respond quickly and reliably to first-world market demands. The automotive industry is the largest manufacturing sector in South Africa.

This article was compiled by means of a survey of light vehicle manufactures in South Africa. Face-to-face semistructured interview questionnaires were used based on the purposive sampling technique. The findings revealed that there are challenges hindering the implementation of supply chain best practices in the South African automotive industry. These include: road freight volumes; delays at port; unreliability of rail; high fuel cost; high operating cost; high cost at ports; high prices of materials, which are actually difficult to overcome and are beyond the control of the manufacturers. A few of the challenges are actually avenues for the manufacturers to focus their efforts to become more competitive, such as replacing outdated assembly or manufacturing tools; finding new markets; cancelling customer orders and improving service levels.

This article indicates that 'costly to replace existing assembly or manufacturing tools' is a great challenge for manufacturers. Cost challenges (which include high fuel cost, operating cost, cost due to delays at ports and high prices of components and materials) affect the performance of the industry and its competitive position worldwide. The South African port charges are way higher than any of the BRICS counterparts. This challenge obviously leads to high prices of new vehicles in South Africa and makes South Africa's automotive manufacturers globally uncompetitive and therefore influences automobile exports. Capacity, skills and labour issues were also identified as challenges impacting the performance of local automotive manufacturers in South Africa. Therefore there is a need to improve service levels and to explore new and emerging markets for exports. If consumer fulfilments are attained as first priority, then the industry will have to work even harder to provide the demanding millennium customers with the level of service they expect.

The article further indicates that there was not much perceived difference in supply chain challenges between the different parent companies of origin in South Africa, except for three challenges. At 5\% significance level, there is a difference in the way that European and Asian manufacturers perceive three key supply chain challenges. 
Asian manufactures feel much stronger about adequacy of their information systems compared to the European manufacturers. Asian manufactures tend to agree more than their European counterparts that labour problems were a challenge. European manufacturers, on the other hand, tend to agree more that rail transport is unreliable.

\section{Acknowledgements Competing interests}

The authors declare that they have no financial or personal relationship(s) that may have inappropriately influenced them in writing this article.

\section{Authors' contributions}

I.M.A. (University of South Africa) and J.A.B-W. (University of South Africa) were equally responsible for the writing of this article.

\section{References}

Afsharipour, A., Afshari, A. \& Sahaf, L., 2006, E-procurement in the automobile supply Chain of Iran, MA thesis, Sweden.

AIEC, 2013, Automotive export manual, Arcadia, Pretoria, South Africa.

AIEC, 2012, Automotive export manual, Arcadia, Pretoria, South Africa.

Ambe, I.M. \& Badenhorst-Weiss, J.A., 2011, South African automotive industry: Trends and challenges in the supply chain, Journal of Contemporary Management $8,337-362$

AutoWorld, 2010, Motor industry needs to address challenges, viewed 08 May 2010 from http://www.autoworld.co.za/newsarticle.aspx?article=3706

Barnes, J. \& Morris, M., 2008, Staying alive in the global automotive industry: What can developing economies learn from South Africa about linking into global automotive value chains? European Journal of Development Research 20(1), 3155. http://dx.doi.org/10.1080/09578810701853157

Black, A., 2001, Globalisation and restructuring in the South African automotive industry, Journal of International Development 13(6), 779-796. http://dx.doi. org/10.1002/jid.812

Braese, N., 2005, The dynamics of supply chains in the automotive industry, MA thesis, Massachusetts Institute of Technology, USA.

Christopher, M., 2005, Logistics and supply chain management: Creating value-adding networks, 3rd edn., Prentice Hall, Harlow, England.

Commonwealth of Australia, 2008, Review of Australia's automotive industry viewed 08 July 2009, from http://www.innovation.gov.au/automotivereview/ Documents/AutomotiveReview2008Backgroundpaper.pdf

Cooney, S. \& Yacobucci, BD., 2005, US automotive industry: policy overview and recent history, Congressional Research Service, viewed 16 June 2009, from http://www. cnie.org/NLE/CRSreports/05apr/RL32883.pdf

Deloitte Touche Tohmatsu, 2009, A new era: Accelerating toward 2020-An automotive industry transformed, viewed 20 November 2011, from https://www. deloitte.com/assets/DcomGlobal/Local\%20Assets/Documents/A\%20New\%20 Era_Online_final.pdf Department of Trade \& Industry (DTI), 2004, Current developments in the automotive industry, viewed 23 November 2011, from www. thedti.gov.za

Gray, P.S., Williamson, J.B., Karp, D.A. \& Dalphin, J.R., 2007, The research imagination: An introduction to qualitative and quantitative methods, Cambridge University Press, New York. http://dx.doi.org/10.1017/СBO9780511819391

Humphrey, J. \& Memedovic, O., 2003, The global automotive industry value chain: What prospects for upgrading by development countries?, United Nations Industrial Development Organization (UNIDO), Vienna.

Hugo, W.M.J., Badenhorst-Weiss, J.A. \& Van Biljon, E.B.H., 2004, Supply chain management: Logistics in perspective, 3rd edn., Van Schaik, Pretoria. PMCid:PMC1388732

Kehbila, A.G., Ertel, J. \& Brent, A.C., 2009, 'Strategic corporate environmental management within the South African automotive industry: Motivations, benefits, hurdles', Corporate Social Responsibility and Environmental Management,16(6), 310-323. http://dx.doi.org/10.1002/csr.188

Klemencic, E. 2006, Management of supply chain: Case of Danfoss District heating business area, MA thesis, Faculty of Economics, Ljubljana University, Slovenia.
Kotler Marketing Group, 2009, Sales best practices in the global automotive supplier industry, Kotler Marketing Group, Washington, DC.

Lam, K., 2008, Oracle for Automotive Sales and Distribution; ORACLE, viewed 20 May 2010, from http://www.oracle.com/us/industries/automotive/018916.pdf

Lambert, D.L., 2006, Supply chain management: Processes, partnerships, performance, 2nd edn., Hartley Press, Florida.

Lamprecht, N., 2009, 'The impact of the Motor Industry Development Programme (MIDP) on the export strategies of the South African light motor vehicle manufacturers', PhD thesis, University of South Africa, Pretoria.

Leenders, M.R. \& Fearon, H.E., 2004, Purchasing and supply chain management, 11th edn, Irwin, Chicago.

Mphahlwa, M.P., 2008, Automotive development programme announcement, viewed 02 July 2009, from www.dti.gov/za/articleview.asp

Muller, M.L., 2009, 'Current automotive industry: How a leader practices competitive intelligence', Competitive Intelligence 11(3), September.

Nag, B., Benerjee, S. \& Chatterjee, R., 2007, 'Changing features of the automobile industry in Asia: Comparison of production, trade and market structure in industry in Asia: Comparison of production, trade and market structure in
selected countries', Asia-Pacific Research and training network on Trade, Working selected countries', Asia-Pacific
paper series, $\mathrm{Nr} 37$, July 2007.

Naude, M.J.A., 2009, Supply chain management problems experienced by South African automotive manufacturers, PhD thesis, University of South Africa, Pretoria.

Naude, M.J. \& Badenhorst-Weiss, J.A., 2011, 'Supply chain management problems at South African automotive component manufacturers', South African Business Review (15)1, 70-99.

Organisation Internationale des Constructuers d'Automobiles (OICA), 2008, viewed 01 January 2010, from www.oica.net

Organisation Internationale des Constructuers d'Automobiles (OICA), 2009, viewed 01 June 2010, from www.oica.net

Pires, R.I.S. \& Neto, M.S., 2008, 'New configurations in supply chains: The case of a condominium in Brazil's automotive industry', Supply Chain Management: An International Journal 13 (4), 328-334.

Pires, S. \& Cardoza, G., 2007, 'A study of new supply chain management practices in the Brazilian and Spanish auto industries', International Journal of Automotive Technology and Management 7 (1), 72-87. http://dx.doi.org/10.1504/ IJATM.2007.013384

Schwarz, M., 2008, Trends in the Automotive Industry: Implications on Supply Chain Management, Cisco Internet Business Solutions Group (IBSG), White paper.

Supply chain foresight, 2007, Survey conceptualised and initiated by Barloworld Logistics, South Africa, viewed 06 June 2008, from http://www. supplychainforesight.co.za

Supply chain foresight, 2010, Survey conceptualised and initiated by Barloworld Logistics, South Africa, viewed 01 May 2010, from http://www.supplychainforesight. co.za

Supply chain intelligence report (CSIR), 2009, Auto industry crisis-part own making, viewed 22 June 2010, from http://www.bizcommunity.com/Article/196/168/38180. html

Swiecki, B. \& Gerth, R.J., 2008, Collaboration in the automotive supply chain: Realizing the full potential of a powerful tool, Centre for Automotive Research, Center for Automotive Research, Manufacturing, Engineering \& Technology Group, Ann Arbor, MI.

Tang, D. \& Qian, X., 2008, Product lifecycle management for automotive development focusing on supplier integration, Computers in Industry 59, 288-295. http:// dx.doi.org/10.1016/j.compind.2007.07.002

Van der Merwe, N. \& Visser, S.S., 2008, Performance management in the motor manufacturing industry of South Africa, Meditari 16(2), 189-211.

Veloso, F. \& Kumar, R., 2003, The automotive supply chain: Global trends on Asian perspectives, ERD Working paper series no. 3.

Viljeon, N., 2012, South African logistics must gear up for change to become global partner, viewed 24 May 2013, from http://www.csir.co.za/enews/2012_july/07. html

Walker, A., 2006, Motor Industry needs to address challenges, viewed 20 November 2011, from http://www.carshop.co.za/NewsArticle.aspx?Article=3706

Wisner, J.D., Tan, K-C. \& Leong, G.K., 2008, Principles of supply chain management: $A$ balanced approach, South-Western Cengage Learning, Mason, $\mathrm{OH}$.

Wei, C.M. \& Chen, C.Y., 2008, 'An empirical study of purchasing strategy in the automotive industry', Industrial Management and Data System 108(7), 973-987. http://dx.doi.org/10.1108/02635570810898026

World Bank Logistics Performance Index (WBLPI), 2012, International Logistics Performance Index, viewed 23 May 2013, from http://Ipisurvey.worldbank.org

Zhang, X. \& Chen, R., 2006, 'Forecast-driven or customer-order-driven? An empirical analysis of the Chinese automotive industry', International Journal of Operations and Production Management 26(6), 668-688. http://dx.doi. org/10.1108/01443570610666993 